\title{
DIRECTIONS OF LEGISLATIVE AND ADMINISTRATIVE CHANGE IN THE MANAGEMENT OF MOTOR ROADS OF UKRAINE
}

\section{НАПРЯМКИ ЗАКОНОДАВЧИХ ТА АДМІНІСТРАТИВНИХ ЗМІН В УПРАВЛІННІ АВТОМОБІЛЬНИМИ ДОРОГАМИ УКРАЇНИ}

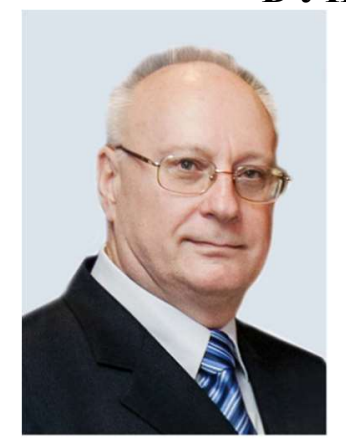

\begin{abstract}
Osayev Yuriy, Candidate of Technical Sciences, Associate Professor, National Transport University, Associate Professor of the Department of Transportation Construction and Property Management, e-mail: osiaev@ukr.net +380964822206,
\end{abstract}

https://orcid.org/0000-0001-7282-600X

Annotation. The state of public highways undoubtedly affects the quality of cargo and passenger transport ation, the level of prices, the degree of employment of the population and the pace of economic development of the state. Consequently, the development of the network management system for highways and improvement of their transport and operational condition is a prerequisite for further socio-economic development of the state and society.

Of particular importance are the research directions of the administrative and legal principles of management in the field of motor roads in Ukraine, since the geographical location of Ukraine, subject to the integration of domestic transport infrastructure into the European one, will allow in the future to receive annual international transit transport by road and tourist trips, significant development of international cooperation of the state and significant revenues to the state budget of the country.

The article defines the directions of legislative and administrative changes in the management of motor roads of Ukraine.

Keywords. Laws of Ukraine in the field of roads, areas of research of administrative and legal principles of management in the field of roads in Ukraine, the state management of roads

By resolution of Cabinet of Ministers of Ukraine from March, 21 in 2018 N 382 the Government having a special purpose economic program of development of highways of the general use of state value was ratified on 2018 - 2022. The Program aim are renewal and development of highways of the general use of state value for integration of them to the European transport system and increase on them of strength of motion, speed, comfort and economy of transportations security. (7)

The Ukrainian State Road Transport Agency Ukravtodor is an integral part of the unified transport system of Ukraine.

The state of highways of the general use indisputably influences on quality of transportation of loads and passengers, standard of prices, degree of employment of population and rates of development of economy of the state.

Thus, development of control system by the network of highways and improvement of them the transport-operating state is necessary pre-condition of further socio-economic development of the state and society. The special value is acquired by directions of researches of administrative-legal

principles of management in the field of highways in Ukraine, as a geographical location of Ukraine on condition of integration of a home transport infrastructure in European will give an opportunity in the future to get annually from transit international transportations by a motor transport and tourist journeys considerable development of international cooperation of the state and ponderable receivabless in the state budget of country. 
The main problem is that management in the field of transport and operational condition of public highways currently does not contribute to creating the necessary conditions for further socio-economic development of the state, strengthening its defense capability and economic security. The study of the property aspect of the state of the network of highways still does not allow to realize the country's potential for further development of public administration in the field of motor roads in Ukraine (5).

The State Department in the field of highways has the following characteristics:

a) is carried out on the basis of laws of Ukraine;

b) has an active, purposeful, nationwide, executive and administrative, organizing character;

c) has its own control object;

d) is expressed in the development of managerial decisions;

e) controls the compliance of the owners of vehicles, as well as citizens, officials with the requirements of the Laws of Ukraine "On Roads", "On Road Traffic", rules, norms, standards for ensuring road safety in general and roads, in particular $(1,2)$.

When it comes to toll roads, local governments, which ensure the operation of toll roads for public use, are responsible for their technical condition, for compliance with the rules and norms of maintenance and repair of highways and in accordance with the procedure established by law, as well as by law compensate for damages caused to users.

According to the existing legislation, local self-government bodies that manage the operation and development of streets and roads of cities and other settlements are responsible for:

a) the state of the streets and roads of cities and other settlements in accordance with the current norms, including regarding the safety of vehicles and pedestrians;

b) quality of design, construction, reconstruction, repair and maintenance of streets and roads of cities and other settlements;

c) placement of technical means of road traffic organization, objects of road service and advertising carriers;

d) reimbursement of losses to users of streets and roads of cities and other settlements that have arisen due to their unsatisfactory condition, in the manner prescribed by law.

In addition, at the local level, the use of departmental (technological) roads, which includes farm technological roads belonging to legal entities or individuals, is being solved.

There are certain peculiarities of relations between the State Agency of Motor Roads of Ukraine and other bodies of executive power on ensuring road safety.

It was established that regulation of relations between the State Agency of Motor Roads and other bodies of executive power is determined mainly by binding and authorizing norms, namely, according to part 5 of Article 12 of the Law of Ukraine "On Roads", attempts "to observe norms of environmental legislation by road users and initiate attraction to the administrative liability for pollution and clogging of the highway and its strip "; Part 10 of Article 12 of this Law permits "to restrict or prohibit, with the notification of the relevant police department of the Ministry of Internal Affairs of Ukraine, the movement of vehicles in the event of a threat to the life or health of road users, the safety of goods or the possibility of causing damage to public roads, including in difficult weather conditions ".

Authorizing norms regulate a considerable part of state-management relations in the field of highways. Basically, these are the norms that establish the general legal framework for the implementation of public administration in the field of highways.

Thus, the competence of the Cabinet of Ministers of Ukraine is carried out in accordance with Article 4 of the Law of Ukraine "On Road Traffic", bodies of legislative power, regions and cities of republican subordination, respectively, Article 5 of the Law of Ukraine "On Road Traffic", participation of enterprises, institutions and organizations in ensuring road safety, respectively paragraph 1 of Article 12 of the Law of Ukraine "On Road Traffic".

The competence of the Cabinet of Ministers of Ukraine includes: drafting laws, regulations on road traffic and its security, defining the powers of executive authorities; formation of state bodies of management in the field of traffic; coordination of activities of ministries, other central bodies of executive power, associations and local self-government in the sphere of traffic, etc. It is noted that the norms according to clause 1 of Article 12 of the Law of Ukraine "On Road Traffic" are supplemented by the binding norms of paragraphs 2-

Науково-технічний збірник «АВтОмОБІльні дОРОГИ І дОРОЖнє БУдІвницТвО» http://addb.ntu.edu.ua

ISSN 0365-8171 (Print), ISSN 2707-4080 (Online), ISSN 2707-4099 (CD).

AUTOMOBILE ROADS AND ROAD CONSTRUCTION, 2021. Issue 109 
4 of Article 12 of this Law, by imposing obligations on officials responsible for the operation and technical condition of vehicles, officials responsible for the construction, reconstruction, repair, operation and installation of roads, other structures, persons responsible for the operation of roads.

Control and supervision as a means of ensuring lawfulness in the field of public administration of motor roads consists of three areas for consideration of issues of legality in the activities of the authorities in the field of roads, as well as the development of proposals and recommendations for improving administrative changes in the activities of Ukravtodor subdivisions:

1. The direction of control as a means of ensuring the rule of law in the field of motor roads determines that, since public administration is a social phenomenon and is regulated, first of all, by the norms of administrative law, then the legality is the main feature inherent in public administration, the activity of the subject and object of management, the basis of the interconnections between them.

Control (departmental, state, public, internal, etc.) has a special significance as an integral part (element) of management, which ensures a systematic review of the implementation of the Constitution, laws of Ukraine, other normative acts, discipline and law and order, and consists in the intervention of controlling bodies in operational activities controlled bodies, giving them binding instructions for the suspension, modification or cancellation of management acts, enforcement of coercive measures against controlled bodies.

With the help of control there is a "reverse" connection between the subject and the object of management in the field of highways, it becomes possible to adjust management decisions in order to increase the efficiency and effectiveness of public-management activities.

It should be noted that authorized state bodies and their officials, carrying out control activities, form a certain system of supervisory bodies, which should act on the basis of the ultimate purpose of their activities. Such principles are a system of principles of control in the field of public administration of motor roads: objectivity, efficiency, transparency, systematic, regularity, reality.

To this end, it is necessary to analyze the effectiveness of the authority of the bodies of control in the field of motor roads: the Cabinet of Ministers of Ukraine, the Ministry of Infrastructure of Ukraine, other ministries, legislative and executive authorities, regions and cities of republican subordination, bodies of sanitary and epidemiological service.

Particular attention should be paid to the direction of study of such kind of special control in the field of highways, as dimensional and weight control, its features, organizational and legal principles and procedures for implementation.

2. The direction of supervision as a way to ensure legality in the field of highways. At the same time it is necessary to take into account the peculiarities of supervision in the sphere of highways, which consist of methods, methods and measures of supervision carried out by "Ukravtodor". It should be noted that in accordance with the Law of Ukraine "On the Basic Principles of State Supervision (Control) in the Sphere of Economic Activity," the legislator identifies the notion of "state supervision" and "state control" and considers them as the activities of authorized central bodies of executive power, their territorial bodies, bodies of local self-government, other bodies within the powers, envisaged by law to detect violations of the requirements of legislation by economic entities and prevent them, to ensure the interests of society, in particular, the proper quality of products, property and services, an acceptable level of danger to the population and the environment. Taking into account the discussion of the question of the relation between concepts of "control" and "supervision" in the theory of administrative law, it is noted that supervision is investigated as a kind of state control, which is characterized by peculiarities inherent only to him.

The methods of supervisory activity of Ukravtodor, in general, can be defined as follows:

a) to supervise the observance of the requirements of legislation on the use and protection of roads of general use and the corresponding property;

b) to conduct investigation of the causes of accidents and accidents on motor roads, as well as to conduct official investigations;

c) to supervise the state of work on the prevention of offenses at enterprises, institutions and organizations of the road economy;

d) monitor the internal and external markets for construction, repair and maintenance of highways;

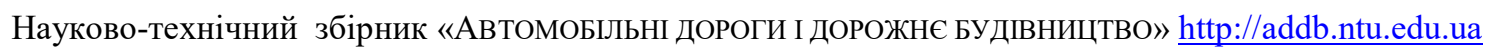
ISSN 0365-8171 (Print), ISSN 2707-4080 (Online), ISSN 2707-4099 (CD).

AUTOMOBILE ROADS AND ROAD CONSTRUCTION, 2021. Issue 109 
e) to implement state policy in the sphere of state secrets protection, to carry out, in the established manner, control over the state of protection and preservation of state secrets in the central apparatus of Ukravtodor, at enterprises, institutions and organizations belonging to the sphere of its management.

3. Direction of use of modern information technologies in the management of the State Agency of Motor Roads of Ukraine "Ukravtodor". There is a need to apply a systematic approach to solving the problem of informatization of control and supervision activities of Ukravtodor subdivisions. Formulate recommendations for the formation of an informational system of public administration in the field of highways, which will include central, regional and local levels.

It should be noted that strategic tasks must be solved at the central level.

The regional level of the information system should address the tasks of ensuring the state of highways at the level of individual regions and cities of regional subordination, as well as to monitor the work of bodies and units at the local level.

The local level of the information system of the state administration in the field of highways is the basic level at which the information system unites the units of "Ukravtodor", the city (paradise), internal affairs bodies, separate bodies and units of the Ministry of Internal Affairs and the Ministry of Emergencies of Ukraine into a single unit. Particular attention should be paid to the issues of information exchange between the next parts of "Ukravtodor", the city (paradise) of the internal affairs departments of the Ministry of Internal Affairs of Ukraine and the Ministry of Emergencies of Ukraine.

Territorial units of the Ministry of Internal Affairs and the Ministry of Emergencies of Ukraine, the Ukravtotrans and the Holovavtotransinspektsiya of the Ministry of Infrastructure, "Ukravtodor" in the event of deterioration of traffic conditions or traffic violations exchange information about the state of travel in the regions, cooperate on coordination and action measures to ensure uninterrupted and safe traffic vehicles and the decisions taken to ensure the conditions

Road traffic is reported to the central authorities via regular or through dispatching services, provided that they are in the mode of telephone and fax communication or by e-mail (3).

Such ranks on the basis of analysis of the current legislation and practice of its application can formulate a number of suggestions and recommendations aimed at improving the administrative and legal framework for management in the field of motor roads in Ukraine, namely:

1. The state administration in the field of motor roads is defined as the enforcement activity of authorized bodies of the state executive power and bodies of local self-government, the functioning of which is aimed at protecting constitutionally fixed vital interests, first of all, life, rights and freedoms, as well as interests in meeting the needs for the movement of participants of the road - citizens, stateless persons and foreign citizens - pedestrians and drivers.

2. The subjects of state administration in the field of highways are the executive authorities, their officials who have the appropriate powers: the Ministry of Infrastructure of Ukraine, the State Agency of Motorways of Ukraine Ukravtodor, the Customs Committee of Ukraine, the Ministry of Finance of Ukraine, the Ministry of Regional Development, construction and housing and communal services of Ukraine, the Antimonopoly Committee of Ukraine, the State Property Fund, as well as local executive bodies and local selfgovernment bodies.

3. The object of public administration in the field of motor roads is the social relations that arise in the field of ensuring the proper condition and development of highways. Relations within each of the subjects of management can be defined as intra-system relations in the field of public administration of motor roads, and relations that arise in the process of implementation between the subjects of management in the field of motor roads of their powers, are external systems. include:

4. Public relations that arise in the implementation of public administration in the field of highways

1) relations arising in the process of construction and operation of highways;

2) relations arising in the process of using motor roads, that is, traffic (between road users);

3 ) relations arising in the process of ensuring the safety of motor roads, ie liability for violations of traffic rules.

Науково-технічний збірник «АВтОмОБІльні дОРОГИ І дОРОЖнє БУдІвницТвО» http://addb.ntu.edu.ua

ISSN 0365-8171 (Print), ISSN 2707-4080 (Online), ISSN 2707-4099 (CD).

AUTOMOBILE ROADS AND ROAD CONSTRUCTION, 2021. Issue 109 
One can assume that each of the components is governed by certain norms of the current legislation, which constitute separate legal sub-institutes of administrative law, which together constitute the legal institute of management in the field of highways:

a) Institute of Road Traffic;

b) Institute for the regulation of behavior of road users;

c) institute of responsibility.

5. Principles of public administration in the field of motor roads can be defined as general, specific and structural. The general principles can be attributed to: objectivity, universality, democracy, legitimacy. By specific - the division of powers, delegation of authority, social orientation, optimization of management, integrity, manageability, controllability, transparency, the combination of collegiality and unity of command. Structural principles can include structural-target, structural-functional, structural-organizational, structuralprocedural principles.

With regard to public administration in the field of highways, structural-organizational and structural-procedural principles are of particular importance. Structural-target and structural-functional principles should be distinguished in the event that there is a problem of matching goals and optimization of functions of different subsystems (6).

6. Public administration in the field of highways has the following features:

a) carried out on the basis of the law;

b) has an active, purposeful, nationwide, executive and administrative, organizing character;

c) has its own control object;

d) realizes the requirements of the law by implementing law enforcement and law-making activities;

e) develops managerial decisions;

f) controls the compliance by the owners of vehicles, as well as citizens, officials of the requirements of the Law of Ukraine "On Road Traffic" - rules, norms, standards for ensuring road safety.

7. Stages of the state management in the field of motor roads:

a) preparation for the management decision;

b) management decision making;

c) execution of managerial decision;

d) control over the execution of a management decision;

e) adjustment in case of unsatisfactory performance of management decision.

8. Management decision as the main form of management in the field of highways is characterized by the following features:

a) has executive, volitional character;

b) is accepted by authorized state authorities (their officials);

c) is a form of expression of the purposeful control of the subject of public administration on its object;

d) has a mandatory or recommendatory character for an object of management; e) is an action by which the management problem is solved;

f) has a conscious character.

9. The main directions of activity of the Cabinet of Ministers of Ukraine concerning management in the field of highways are:

a) formation of state authorities in the field of motor roads, management of their activities;

b) development and approval of state programs of development and safety in highways, streets and railway crossings, environmental safety requirements, as well as programs for coordinating the use of all types of public transport; security;

c) financing and control over the implementation of state road traffic development programs and their

d) determination of the procedure for issuing licenses and certificates and carrying out activities related to the carriage of goods and passengers, training of drivers, construction, reconstruction, repair and maintenance of highways, streets and railroad crossings, with other types of activities that affect traffic safety.

10. It is established that when forming an informational system of management in the field of motor roads, the following should be taken into account: 
a) the specialization of separate structural units of the system of public administration (it means the definition of the circle of management entities, the definition of their competence, the specificity of the implementation of interrelations);

b) definition of a public body with a broader scope of public administration in the field of motorways (the aspect of concentration of authority);

c) Decentralization of management decisions (determining the range of officials who directly make managerial decisions and form information flows, taking into account the specifics of their activities and the scope of authority).

11. The legal mode of motor roads is a system of norms, rules, tools that regulate social relations that arise in the implementation of public administration in the field of motorways of Ukraine.

\section{Conclusions}

On the basis of the above, it can be noted that the main directions of improvement of the functions of management of road economy of Ukraine are:

a) Optimization of the network of highways in accordance with the requirements of the development of the state economy;

б) reforming the existing system of maintenance of roads of state importance by introducing a regionallinear principle of their servicing by specialized road-operation enterprises;

в) Performing works on construction, reconstruction and major repair of roads should be conducted on a competitive basis with the introduction of international principles for the construction of civil engineering contract (FIDIC) (4).

It must also be agreed with the opinion of experts that any attempts to improve the system of state control and management of the network of roads, introducing sporadic changes to the legislation or adopting new subordinate acts, will not be very successful. The effectiveness of each such measure will be offset by the general imperfection of the legal basis, its numerous deficiencies, problems and imbalances.

Only radical reform can fundamentally change the situation, which would not simply optimize the content of sectoral legislation but also integrate it into an integrated system with the same principles of organization, operation and development (8) .

The first stage and at the same time the cornerstone of such a reform should be the adoption of the Law of Ukraine "On Public Audit on Road Transport" - a law that outlines the basics of sectoral control, defines its general principles, goals and priorities, and serves as the basis for standard setting in the relevant area of management activity.

1.Zakon Ukrayiny` «Pro avtomobil 'ni dorogy`»

2.Zakon Ukrayiny` «Pro dorozhnij rux»

3. Pro vnesennya zmin do deyaky`x zakoniv Ukrayiny` shhodo reformuvannya sy`stemy` upravlinnya dorogamy`zagal’nogo kory`stuvannya: zakon Ukrayiny`vid 11.11.2016 r. - [Elektronny`j resurs]. - Rezhy`m dostupu: http://zakon3.rada.gov.ua/ 1 ashB/z'osh/1764-19

4. Pro zatverdzhennya vy'mog shhodo provedennya kontrolyu yakosti robit z novogo budivny'cztva, rekonstrukciyi ta kapital nogo remontu avtomobil’ny`x dorig zagal`nogo kory`stuvannya: Postanova Kabinetu Ministriv Ukrayiny` \# 1065 vid 28 grudnya 2016 r. - [Elektronny’j resurs]. - Rezhy`m dostupu: http://zakon3.rada.gov.ua/1aws/show/1065-2016-DBF.

5.Maslova Ya.I. Reformuvannya sy`stemy` derzhavnogo upravlinnya avtomobil'ny`my` dorogamy` zagal'nogo kory`stuvannya / Ya.I. Maslova // Pravove zhy`ttya suchasnoyi Ukrayiny` : tezy` dop. Mizhnar. nauk. konf. profesor.-vy`klad. ta aspirant. skladu (m. Odesa, 21-22 travnya 2010 r.) / Vidp. red. d-r yury`d. nauk, prof. Yu.M. Oborotov // Odes `ka nacional`na yury`dy`chna akademiya. - O. : Feniks, 2010. - S. 324326.

6.Tovstuha S.O. Osobly`vosti udoskonalennya derzhavno-upravlins'ky`x mexanizmiv u sferi bezpeky` dorozhn`ogo ruxu v Ukrayini / S.O. Tovstuxa // Innovaciyi v derzhavnomu upravlinni: sy`stema integraciyi osvity', nauky', prakty'ky’: materialy` nauk.-prakt. konf. za mizhnar. uchastyu ( Ky`yiv,27 trav.2011) .K.: NADU, 2011 - T.1.-S.629-631

7.Postanova Kabinetu Ministriv Ukrayiny`vid 21 bereznya 2018 r. N 382

Науково-технічний збірник «АвТОмОБІльні дОРОГи г дОРОжНє БУдІВНИцТВО» http://addb.ntu.edu.ua

ISSN 0365-8171 (Print), ISSN 2707-4080 (Online), ISSN 2707-4099 (CD).

AUTOMOBILE ROADS AND ROAD CONSTRUCTION, 2021. Issue 109 
8. Maly`novs `ky`j V. Ya. / Derzhavne upravlinnya: Navchal`ny`j posibny`k.- Vy`d. 2-ge, dop. ta pererob.- K.: Atika, 2003.- $576 \mathrm{~s}$.

\section{НАПРЯМКИ ЗАКОНОДАВЧИХ ТА АДМІНІСТРАТИВНИХ ЗМІН В УПРАВЛІННІ АВТОМОБІЛЬНИМИ ДОРОГАМИ УКРАЇНИ}

Осяєв Юрій Миколайвич, кандидат технічних наук, доцент, Національний транспортний університет,доцент кафедри транспортного будівництва та управління майном, e-mail: osiaev@ukr.net тел. +380964822206, https://orcid.org/0000-0001-7282-600X

Анотація. Стан автомобільних доріг загального користування безперечно впливає на якість перевезення вантажів і пасажирів, рівень цін, ступінь зайнятості населення та темпи розвитку економіки держави. Отже, розвиток системи управління мережею автомобільних доріг та поліпшення ïх транспортно-експлуатаційного стану $\epsilon$ необхідною передумовою подальшого соціальноекономічного розвитку держави і суспільства.

Особливого значення набувають напрямки досліджень адміністративно-правових засад управління у сфері автомобільних доріг в Україні, оскільки географічне розташування України за умови інтеграції вітчизняної транспортної інфраструктури в європейську дасть змогу в майбутньому отримувати щороку від транзитних міжнародних перевезень автомобільним транспортом та туристичних поїздок значний розвиток міжнародного співробітництва держави та вагомі надходження до державного бюджету країни.

У статті визначені напрямки законодавчих та адміністративних змін в управлінні автомобільними дорогами України.

Ключові слова. Закони України у сфері автомобільних доріг, напрямки досліджень адміністративно-правових засад управління у сфері автомобільних доріг в Україні, державне управління автомобільними дорогами

1. Закон України "Про автомобільні дороги".

Перелік посилань

2. Закон України "Про дорожній рух".

3. Про внесення змін до деяких законів України від 11.11.2016 - [Електронний ресурс]. - Режим доступу: http://zakon3.rada.gov.ua

4. Про затвердження вимог щодо проведення контролю якості робіт з нового будівництва,реконструкції та капітального ремонту автомобільних доріг загального користування: Постанова Кабінету Міністрів України №1065 від 28 грудня 2016 р. - [ Електронний ресурс] - Режим доступу: http://zakon3.rada.gov.ua

5. Маслова Я.І. Реформування системи державного управління автомобільними дорогами загального користування/ Я.І.Маслова// Правове життя сучасної України: тези доп. міжнародної наукової конференції проф.-виклад.та аспірант. складу (м.Одеса, 21-22 травня 2010)/ Відп.ред. д-р юридичних наук, проф. Ю.М.Оборотов //Одеска національна юридична академія.- Одеса.:Фенікс, 2010. - С.324326.

6. Товстуха С.О. Особливості удосконалення державно - управлінських механізмів у сфері безпеки дорожнього руху в Україні/ С.О.Товстуха//Інновації в державному управлінні: система інтеграції освіти, науки, практики: наук.-практ. конф.з між народ. участю. ( Київ, 27 травня, 2011). К.: НАДУ, 2011 T.1.- C. 629-631

7. Постанова Кабинету Міністрів України від 21 березня 2018 №382.

8. Маліновський В.Ю. / Державне управління: навчальний посібник. - вид.2-ге, доп. та перероб.К.:Атіка,2003.-576 с. 